\title{
TANTANGAN EKONOMI SYARIAH DALAM MENGHADAPI MASA DEPAN INDONESIA DI ERA GLOBALISASI
}

\author{
Anis Mashdurohatun \\ Fakultas Hukum Universitas Islam Sultan Agung Semarang \\ E-mail: ulmiftah19@yahoo.com
}

\begin{abstract}
In essence, globalization is the best means for Muslims to introduce the culture and the teachings of Islam to all corners of the world. Islamic economic challenges including the State that in fact many Muslim population tends to use the capitalist system; In economics and politics in view of the Islamic State is not strong so it is difficult to prove that the Islamic Economic System is superior to the capitalist and socialist, and Among the experts was still disagreement on the definition Islamic Economic System. Islamic Economy Facing Future In Indonesia in the Era of Globalization needs to consider several factors, namely Mastery Technologies, Sharia-based SME Development, Keeping the Sharia Economic Excellence, namely Islamic economic system, and also the prohibition of usury.
\end{abstract}

Keywords: islamic economic, globalization, capitalism

\begin{abstract}
Abstrak
Pada hakikatnya globalisasi merupakan sarana terbaik bagi umat Islam untuk memperkenalkan budaya dan ajaran Islam ke seluruh penjuru dunia. tantangan ekonomi syariah diantaranya banyak Negara yang notabene berpenduduk Islam cenderung menggunakan sistem kapitalis;Secara ekonomi dan politik Negara Islam di pandang tidak kuat sehingga sulit untuk membuktikan bahwa Sistem Perekonomian Islam lebih unggul daripada kapitalis dan sosialis;serta Diantara para ahli sendiri masih silang pendapat tentang pengertian Sistem Perekonomian Islam. Ekonomi Syariah Dalam Menghadapi Masa Depan Indonesia di Era Globalisasi perlu memperhatikan beberapa faktor, yaitu Penguasaan Teknologi, Pengembangan UKM berbasis Syariah, Menjaga Keunggulan Ekonomi Syariah, yaitu sistem ekonomi syariah, dan juga pelarangan riba.
\end{abstract}

Kata kunci: ekonomi syariah, globalisasi, kapitalisme

\section{Pendahuluan}

Globalisasi ekonomi sebenarnya sudah terjadi sejak lama, masa perdagangan rempahrempah, masa tanaman paksa (cultuur stelsel) dan masa dimana modal swasta Belanda zaman kolonial dengan buruh paksa. Pada ketiga periode tersebut hasil bumi Indonesia sudah sampai ke Eropah dan Amerika. ${ }^{1}$ Sebaliknya impor tekstil dan barang-barang manufaktur.

\footnotetext{
Lihat antara lain Daniel Chirot,1986, Social Change in The Modern Era, San Diego, New York: Harcourt Brace Jovanovich, Inc hlm. 32-35; H.R.C. Wright,1961, EastIndian Economic Problem of the Age of Cornwallis \& Raffles, London: Inzac and Company, Ltd., hlm. 16; Robert Van Neil, 1964, "The Function of Land Rent Under the Cultivation Sistem in Java," Journal of Asian Studies 23, hlm. 359; dan R.E. Elson, 1984, Javanese Peasants and the Colonial Sugar Industri, London: Oxford University Press, hlm. 34-35.
}

betapapun sederhananya, telah berlangsung lama. ${ }^{2}$

Globalisasi ekonomi sekarang ini adalah manifestasi yang baru dari pembangunan kapitalisme $^{3}$ sebagai sistem ekonomi internasional,

C.Fasseur, 1986," The Cultivation Sistem and Its Impact on the Dutch Colonial Economy and the Indigenous Society in Nineteenth Century Java," dalam Two Colonial Empires, ed, C.A, Bayly and D.H.A.Kolf, Dordrecht: Martinus Nijhoff Publishers, hlm.137.

3 Kapitalisme, menurut Weber, menuntut suatu tatanan normatif dengan tingkat yang dapat diperhitungkan (calculability atau predictability) secara akurat. Hasil penelitian Weber terhadap sistem-sistem hukum yang ada di zamannya, sampai pada kesimpulan bahwa hanya hukum modern yang rasional atau memiliki rasionalitas formal yang bersifat logis yang mampu memberikan tingkat perhitungan yang dibutuhkan. Legalisme atau pandangan yang menempatkan peraturan perundang-undangan sebagai sumber hukum utama dan terpenting, dipandang memberikan dukungan kepada perkembangan kapitalisme dengan memberikan suasana 
Seperti pada waktu yang lalu, untuk mengatasi krisis, perusahaan multinasional mencari pasar baru dan memaksimalkan keuntungan dengan mengekspor modal dan reorganisasi struktur produksi. Pada tahun 1950 an, investasi asing memusatkan kegiatan penggalian sumber alam dan bahan mentah untuk pabrik-pabriknya. Tiga puluh tahun terakhir ini, perusahaan manufaktur menyebar keseluruh dunia. Dengan pembagian daerah operasi melampaui batas-batas negara, perusahaan-perusahaan tak lagi memproduksi seluruh produk disatu negara saja. Manajemen diberbagai benua, penugasan personel tidak lagi terikat pada bahasa, batas negara dan kewarganegaraan. ${ }^{4}$

Pada masa lalu bisnis internasional hanya dalam bentuk export import dan penanaman modal. Kini transaksi menjadi beraneka ragam dan rumit seperti kontrak pembuatan barang, waralaba, imbal beli, "turnkey project," alih teknologi, aliansi strategis internasional, aktivitas financial, dan lain-lain. ${ }^{5}$ Globalisasi menyebabkan berkembangnya saling ketergantungan pelaku-pelaku ekonomi dunia. Manufaktur, perdagangan, investasi melewati batasbatas negara. meningkatkan intensitas persaingan. Gejala ini dipercepat oleh kemajuan komunikasi dan transportasi teknologi. ${ }^{6}$

yang stabil dan dapat diperhitungkan. (lihat David $M$. Trubek, "Max Weber on Law and The Rise of Capitalisme", Winconsin Law Review, Vol 3, 1992, hlm. 740. Lihat juga Francis Fukuyama, 2001, Kemenangan Kapitalisme dan Demokrasi Liberal (Diterjemahkan dari judul asli The End of History and The Last Man)a Yogyakarta: Qalam, hlm. 406, 407; Anthony Giddens, 1986, Kapitalisme dan Teori Sosial Modern (Suatu analisis karya-karya Marx, Durkheim dan max Weber), Jakarta: UI Press, hlm. 153,154. Lebih lanjut, menurut Max Weber, jika hukum hendak difungsikan dalam memfasilitasi kehidupan ekonomi, maka harus diciptakan hukum yang memiliki beberapa karakteristik, yakni: predictability,stability, fairness, education, special ability of the lawyer. Lihat Thomas N. Frank, "The New Development, Can American Law and Legal Institution Help Developing Countries?", Wisconsin Law Review, 1989, hlm. 206.)

4 Richard C. Breeden,"The globalization of Law and Business in the 1990s," Wake Forest Law Review, vol.28 No. 3 1993, hlm. 514.

5 S. Tamer Cavusgil, "Globalization of Markets and Its Impact on Domestic Institutions." Global Legal Studies Journal, Vol 1, 1993, hlm. 83-86.

6 Jaqnes Delors, 1995, "The Future of Free Trade in Europe and the World," Fordham International Law Journal. Vol. 18, h. 723.
Dampak dari globalisasi sangat kompleks, meliputi liberalisasi dalam sistem perdagangan dunia, peningkatan mobilitas tenaga kerja dan modal, pembentukan blok perdagangan dan penyebarluasan teknologi serta komunikasi. ${ }^{7}$

Kwakwa menyatakan bahwa efek terpenting globalisasi adalah munculnya pergeseran dari sistem ekonomi nasional yang berbedabeda, ke arah ekonomi internasional dimana produksi menjadi mendunia dan modal serta uang bergerak secara cepat dan tidak terelakkan, melintasi batas Negara-negara. Globalisasi yang terjadi pada perusahaan dan pasar juga menggerogoti hukum nasional, dan dalam kasus tertentu dapat menyebabkan konflik antara kebijakan nasional dan kepentingan internasional. Sektor privat di wilayah internasional (diwakili oleh perusahaan-perusahaan transnasional) memainkan peran yang semakin signifikan dalam penentuan kebijakan ekonomi baik di tingkat nasional maupun global.

Santos menyatakan bahwa besarnya arus import di negara-negara maju, serta aliran investasi asing (Foreign Direct Investment) ke negara-negara tersebut telah mengakibatkan peningkatan ketidakmerataan pendapatan, kehilangan pekerjaan dan rendahnya upah bagi pekerja kurang terampil. Sedangkan di negaranegara berkembang, globalisasi memberikan legitimasi bagi internasional untuk menekan Negara berkembang agar melakukan proses penyesuaian dan restrukturisasi kebijakan dan dengan demikian menerima hegemoni kapital internasional dalam wilayah Negara. ${ }^{8}$

Kekhawatiran pada dampak globalisasi ekonomi tersebut,telah memicu para aktivis dunia melakukan aksi penentangan globalisasi ekonomi dan liberalisasi perdagangan, karena dikhawatirkan akan memperbesar kesenjangan

7 Dian Rosita, 2010, "Kedaulatan Negara dalam Pembentukan Hukum di Era Globalisasi ,Jakarta; I http:// www.leip.or.id/. Baca juga Damianus J. Hali, "Humanisme dan Peradaban Global", Jurnal Hukum Pro Justitia Vol. 26 No. 2 April 2008 FH Unpar Bandung, hlm. 111-127; Victor Purba, "Peranan Hukum dalam Global Kompetisi pada Era Globalisasi”, Majalah Hukum Pro Justitia Tahun XII No. 2 April 1994 FH Unpar Bandung, hlm. 56-62.

8 Kwakwa, Edward,2000," Regulating The International Economy, What Role For The State," dalam Michael Byers, hlm.217. 
ekonomi, yang justru menciptakan petaka kemanusiaan. Pada sisi lain, berbagai pihak berharap pula agar WTO yang beranggotakan 147 negara, akan mampu menjaga kepentingan anggotanya dari negara-negara berkembang sebagaimana ditegaskan dalam Putaran Doha, Qatar, tahun 2001.

Putaran Doha menekankan perdagangan dunia yang lebih berimbang dengan memberikan akses lebih besar kepada negara-negara berkembang. Sebab jika perdagangan dunia berlangsung tidak seimbang, liberalisasi perdagangan akan menciptakan malapetaka ekonomi bagi negara-negara berkembang. Malapetaka ekonomi yang dikhawatirkan itu dapat saja terjadi, terutama karena kebanyakan negara berkembang saat ini belum siap menghadapi persaingan global. Perhatian pemerintah Negara-negara berkembang saat ini masih banyak tersedot ke berbagai persoalan dan kesulitan domestik. Kendatipun terdapat kekhawatiran bahwa liberalisasi perdagangan kurang lebih merupakan bentuk imperialisme baru (neoimperialism), dalam arti bahwa keterlibatan negara-negara sedang berkembang dalam aktivitas perdagangan bebas mengandung resiko yang sangat besar, namun keharusan ikutserta dalam dunia ekonomi global dan perdagangan bebas merupakan sesuatu yang tidak mungkin dihindarkan tanpa resiko terkucilkan dalam percaturan kehidupan dunia. Sedangkan Negara-negara maju dapat memaksakan pendapatnya yang merugikan negara-negara berkembang, sehingga muncul penilaian bahwa liberalisasi perdagangan tidak lebih merupakan bentuk penjajahan baru Negara-negara utara atas negara-negara selatan. ${ }^{9}$

Fenomena kebangkrutan perusahaan besar di Amerika Serikat membuktikan bahwa mereka hanya mengejar keuntungan dengan meng-

Dochak Latief, Perekonomian Indonesia Di Tengah Liberalisasi Perdagangan dan Pertumbuhan Ekonomi Asia-Pasifik Abad-21, dalam Khudzaifah Dimyati \& Kelik Wardiono ed., 2004, Problema Globalisasi Perspektif Sosiologi Hukum, Ekonomi dan Agama, Surakarta: Muhammadiyah University Pers, hlm. 166. Lihat juga Taryana Soenandar, "Perdagangan Bebas dan Harmonisasi Hukum: Kajian atas Doktron "Lex Mercatoria", Jurnal Keadilan Vol. 1 No. 5 November-Desember 2001, hlm. 1-4. halalkan segala cara. Kasus Enron dan Arthur Andersen, memanipulasi akuntansi laporan keuangan untuk meningkatkan keuntungan, ternyata berdampak pada kehancuran raksasa tersebut.

Krisis ekonomi kapitalis telah terjadi berulangkali. Dari Rusia sampai ke Venezuela dalam kurun waktu 50 tahun terakhir ini, menyebabkan penderitaan ekonomi, pendapatan menurun, kelaparan, kerusuhan, dan meningkatnya kriminalitas. Bila diperhatikan visi ekonomi kapitalis ternyata lebih mengutamakan pemilik modal, memperlakukannya sebagai motor penggerak, inisiator, leader dan otomatis akan menjadi penerima berkah. Di sisi lain, pekerja dan profesional sebegai pelengkap penderita saja. Kapitalisme mengabaikan aspek transendental, moral dan ketuhanan. Dasar filosofi rasionalisme sekuler inilah yang menyebabkan ketidakseimbangan yang berdampak pada kerusakan alam, kemiskinan, kerusuhan sosial, hingga menimbulkan berbagai krisis berkelanjutan. ${ }^{10}$

Fondasi Kapitalisme adalah monetary based economy bukan real based economy, sehingga rente ekonomi yang diperoleh bukan berdasarkan hasil investasi produktif, namun dari investasi spekulatif. Kenyataan bahwa uang yang beredar melalui transaksi di Wall Street adalah US\$ 3 triliun/hari, dimana 90\% kegiatannya spekulatif tanpa kontribusi dalam perluasan lapangan kerja dan rakyat kecil. Sehingga uang sebesar itu tidak menyentuh pada rakyat kecil.

Ekonomi kapitalis tidak pro-UMKM. Perusahaan kecil tetap saja kecil sesuai hukum Deminishing Marginal Return. Perusahaan-perusahaan besar yang mempengaruhi perekonomian dunia antara lain Protecter \& Gamble, Ford General Motors (GM), Westing House \& General Electric (GE) serta Siemens \& AEG. Dari 200 Multi National Corporation menguasai 25\% pasar dunia, namun hanya menyerap $1 \%$ tenaga kerja.

Presiden George Bush pada Maret 2008 mengakui kelemahan sistem kapitalis dan se-

10 Conrad Hendrarto, 2008, "Ambruknya Kapitalis dan Saat Bangkitnya Ekonomi Syariah, hlm. 1-2. 
tuju mengatur kembali semua lembaga keuangan. Pada pertemuan G-8 tahun 2008, di DavosSwiss, George Soros menegaskan gejolak pasar keuangan global tidak bisa diatasi dengan penurunan suku bunga atau penyuntikan dana. Banyaknya kepalsuan dalam laporan keuangan, dan maraknya praktek-praktek penipuan menyebabkan lembaga keuangan global terjerambab dalam kebangkrutan massal. Kondisi keuangan tersebut menunjukan bahwa sistem yang berjalan tidak Islami. Namun yang menjadi pertanyaan saat ini, walaupun Bush menyetujui perubahan sistem ekonomi dunia, dan Soros menyarankan pengaturan pasar uang ketat dan mengurangi kucuran kredit ke sektor spekulatif, apakah mereka melihat potensi ekonomi syariah? Inilah tantangan nyata bagi ekonomi syariah untuk membuktikan bahwa Islam itu rahmatan lil 'alamin.

Sejarah pergerakan ekonomi Islam di Indonesia sebenarnya telah berlangsung sejak tahun 1911, yaitu sejak berdirinya organisasi Syarikat Dagang Islam yang dibidani oleh para entrepreneur dan para tokoh Muslim saat itu. Bahkan jika kita menarik sejarah jauh ke belakang, jauh sebelum tahun 1911, peran dan kiprah para santri (umat Islam) dalam dunia perdagangan cukup besar. Banyak penelitian para ahli sejarah dan antropologi yang membuktilan fakta tersebut.

Clifford Geertz, antropolog AS terkemuka, menyatakan bahwa di Jawa, para santri reformis mempunyai profesi sebagai pedagang atau wirausahawan dengan etos entrepreneurship yang tinggi. Sementara dalam buku "The Religion of Java" (1960), Geertz menulis, Pengusaha santri (muslim) adalah mereka yang dipengaruhi oleh etos kerja Islam yang hidup di lingkungan di mana mereka bekerja. Fakta ini merupakan hasil studi, Clifford Geertz, dalam upaya untuk menyelidiki siapa di kalangan muslim yang memiliki etos entrepreneurship seperti "Etik Protestantisme", sebagaimana yang dimaksud oleh Max Weber. Geertz menemukan, bahwa etos itu ada pada kaum santri yang ternyata pada umumnya memiliki etos kerja dan etos kewiraswastaan yang lebih tinggi dari kaum abangan yang dipengaruhi oleh elemenelemen ajaran Hindu dan Budha.

Perkembangan bank syariah mulai terasa sejak dilakukan amandemen terhadap UU No. 7/1992 menjadi UU No. 10/1998 yang memberikan landasan operasi yang lebih jelas bagi bank syariah. Sebagai tindak lanjut UU tersebut, Bank Indonesia (BI) mulai memberikan perhatian lebih serius terhadap pengembangan perbankan syariah, yaitu membentuk satuan kerja khusus pada April 1999. Satuan kerja khusus ini menangani penelitian dan pengembangan bank syariah (Tim Penelitian dan Pengembangan Bank Syariah dibawah Direktorat Penelitian dan Pengaturan Perbankan) yang menjadi cikal bakal bagi Biro Perbankan Syariah yang dibentuk pada 31 Mei 2001, dan sekarang resmi menjadi Direktorat Perbankan Syariah Bank Indonesia sejak Agustus 2003.

Semakin banyakya jumlah bank syariah, struktur pasar syariah pun berubah dari monopoli menjadi oligopoli, yang menyebabkan semakin tingginya tingkat persaingan diantara bank syariah. Sehingga, agar mampu bersaing dengan bank konvensional, bank inipun mengubah strateginya. Sampai dengan Desember 2003, pemain dalam industri perbankan syariah terdiri dari 2 bank umum syariah (BUS) dan 8 unit usaha syariah (UUS) dari bank umum konvensional (BUK) yang seluruhnya memiliki jaringan kantor berjumlah 119 KCS (Kantor Cabang Syariah), serta 84 BPRS (Bank Perkreditan Rakyat Syariah). Peningkatan jumlah pemain dalam industri perbankan syariah terlihat cukup pesat bila dibandingkan keadaan akhir tahun 1998 yang hanya berjumlah 1 BUS dengan 8 KCS dan 78 BPRS.

Minat investor untuk membuka kantor bank syariah tidak hanya terbatas di pulau Jawa tetapi juga telah menyebar ke pulau lainnya, antara lain: Sumatera (Banda Aceh,Medan, Padang, Palembang dan Pekanbaru); Kalimantan (Balikpapan dan Banjarmasin); Sulawesi (Makasar); Madura (Pamekasan); dan Irian Jaya (Jayapura).

Satjipto Rahardjo mengatakan bahwa berat sekali kalau negara-negara berkembang seperti Indonesia harus menghadapi globalisasi 
kapitalisme dengan cara melawannya. Sejalan dengan perkembangan ekonomi dunia yang telah berlangsung sejak lama, pembagian kerja di dunia sudah berubah dan bangsa-bangsa di dunia harus pandai-pandai meninjau kembali siasat yang dipilihnya dalam rangka perubahan tersebut. ${ }^{11}$ Berdasarkan uraian latar belakang tersebut, penulis akan membahas mengenai tantangan ekonomi syariah dalam menghadapi masa depan indonesia di era globalisasi.

\section{Pembahasan}

Kepercayaan masyarakat merupakan jiwa industry perbankan. ${ }^{12}$ Perkembangan ekonomi syariah, terlihat dalam proses pertumbuhan perbankan syariah dari tahun ke tahun, walau pun pertumbuhan Bank Syariah agak melambat pada tahun 2005, tetapi lihak Bank Indonesia dan juga para stakeholder yang terlibat dalam pengembangan ekonomi dan perbankan Syariah masih mempunyai keyakinan bahwa Bank Syariah akan terus berkembang pada tahun 2006 dan tahun-tahun selanjutnya seiring berkembangnya aplikasi-aplikasi ekonomi berbasiskan prinsip-prinsip Syariah di Indonesia.

Pada hakikatnya globalisasi merupakan sarana terbaik bagi umat Islam untuk memperkenalkan budaya dan ajaran Islam ke seluruh penjuru dunia. Seperti yang telah tercantum dalam Al Quran bahwa tidak ada pemaksaan dalam agama, umat Islam dapat menawarkan budaya, ideologi, dan gaya hidup Islami, kepada dunia dengan menampilkan keteladanan Rasulullah dan para nabi lainnya. Tauhid, kesederhanaan, kejujuran, dan etika, merupakan di antara hikmah Islami yang saat ini dinanti umat manusia modern. Peluang inilah yang harus dimanfaatkan dengan baik oleh umat Islam dalam mewujudkan kehidupan dan masyarakat yang diridhoi oleh Allah.

11 Satjipto Rahardjo, Pembangunan Hukum di Indonesia Dalam Konteks Situasi Global, dalam Khudzaifah Dimyati \& Kelik Wardiono ed., 2004, Problema Globalisasi Perspektif Sosiologi Hukum, Ekonomi dan Agama, Surakarta: Muhammadiyah University Pers, hlm. 12.

12 Zulkarnain Sitompul, "Analisis Hukum Kewenangan Lembaga Penjamin Simpanan Dalam Pembubaran Dan Likuidasi Perseroan Terbatas," Jurnal Hukum Bisnis, Volume 28-No.3-Tahun 2009, hlm. 36.
Tantangan Ekonomi Syariah dalam Menghadapi Masa Depan Indonesia di Era Globalisasi

Ekonomi syariah berpotensi menggantikan posisi ekonomi konvensional, namun dalam penerapannya banyak kendala dan tantangan yang dihadapi antara lain masih diberlakukannya pajak ganda di perbankan syariah; belum siapnya dukungan SDM ekonomi syariah; tidak ada kurikulum ekonomi syariah di sekolah umum, sehingga pemahaman, kesadaran serta kepedulian masyarakat rendah; persepsi negatif sekelompok muslim dan non-muslim yang takut mengaplikasikan hukum syariah secara kafah; belum kuatnya dukungan parpol Islam untuk menerapkan ekonomi syariah; meningkatnya apresiasi masyarakat dan kegairahan memperluas pasar ekonomi syariah belum diikuti dengan edukasi yang memadai;

Menurut identifikasi Bank Indonesia, yang disampaikan pada Seminar Akhir Tahun Perbankan Syariah 2005, kendala-kendala perkembangan Bank Syariah di samping imbas kondisi makro ekonomi, juga dipengaruhi oleh hal-hal sebagai berikut. Pertama, jaringan kantor pelayanan dan keuangan Syariah masih relatif terbatas; kedua, sumber daya manusia yang kompeten dan professional masih belum optimal; ketiga, pemahaman masyarakat terhadap Bank Syariah sudah cukup baik, namun minat untuk menggunakannya masih kurang; keempat, sinkronisasi kebijakan dengan institusi pemerintah lainnya berkaitan dengan transaksi keuangan, seperti kebijakan pajak dan aspek legal belum maksimal; kelima, rezim suku bunga tinggi pada tahun 2005; dan keenam, fungsi sosial Bank Syariah dalam memfasilitasi keterkaitan antara voluntary sector dengan pemberdayaan ekonomi marginal masih belum optimal.

Untuk mengantisipasi kendala jaringan kantor pelayanan Bank Syariah, pihak BI yelah membuat regulasi tentang kemungkinan pembukaan layanan Syariah pada counter-counter Unit Kovensional Bank-Bank yang telah mempunyai Unit Usaha Syariah melalui PBI No.8/3/ PBI/2006 tanggal 30 Januari 2006. Dengan demikian, diharapkan masalah jaringan pelayanan 
dan keuangan Syariah dapat diatasi karena masyarakat dapat dilayani dimana saja saat membutuhkan transaksi Bank Syariah.

Bank Indonesia dan para stakeholder yang terlibat lainnya yakin bahwa pengembangan Bank Syariah dianggap masih mempunyai prospek yang tinggi, jika kendala jaringan dapat diatasi. Hal tersebut diyakini karena peluang yang besar dan dapat dilihat dari hal-hal sebagai berikut. Pertama, respon masyarakat yang antusias dalam melakukan aktivitas ekonomi dengan menggunakan prinsip-prinsip Syariah; kedua, kecenderungan yang positif di sektor non-keuangan/ ekonomi, seperti sistem pendidikan, hukum dan lain sebagainya yang menunjang pengembangan ekonomi Syariah nasional; ketiga, pengembangan instrumen keuangan Syariah yang diharapkan akan semakin menarik investor/ pelaku bisnis masuk dan membesarkan industri Perbankan Syariah Nasional; dan keempat, potensi investasi dari negara-negara Timur Tengah dalam industri Perbankan Syariah Nasional.

Berkaitan dengan tantangan ekonomi syariah yang harus di hadapi oleh bangsa Indonesia untuk menuju kemajuan ekonomi syariah adalah sistem kapitalis khususnya, terlanjur mendominasi sistem perekonomian di dunia bahkan banyak Negara yang notabene berpenduduk Islam cenderung menggunakan sistem kapitalis walaupun dalam penerapannya terdapat modifikasi; secara ekonomi dan politik tidak Negara Islam yang di pandang kuat sehingga sulit untuk membuktikan bahwa sistem perekonomian Islam lebih unggul daripada kapitalis dan sosialis; dan di antara para ahli sendiri masih silang pendapat tentang pengertian Sistem Perekonomian Islam. ${ }^{13}$

Hal-hal yang perlu diperhatikan ekonomi syariah dalam menghadapi masa depan Indonesia di Era Globalisasi, diantaranya adalah sebagai berikut. Pertama, penguasaan teknologi. Menurut sebagian ekonom perkembangan teknologi merupakan bagian yang paling penting dari determinan-determinan suatu pembangunan ekonomi.

13 Muhammad, 2004, Ekonomi Mikro dalam Perpektif Islam, Yogyakarta: BPFE,hlm. 6-7.
Lebih jauh lagi Schumpter mengatakan bahwa "Economic Growth does not follow a gradual, historical and continuous process; it occurs by discontinuous spurts in dynamic world. This dynamism and discontinuous process is facilitated by innovation leading to technological change." 14

Islam menganjurkan adanya Inovasi dan perkembangan teknologi. Hanya saja Islam lebih menekankan Appropritate Technology bukan sophisticated technology. Suatu hal yang kurang dipahami oleh kebanyakan Negara muslim sehingga mereka banyak dirugikan oleh teknologi bukan mengambil kemanfaatan darinya.

Ada tiga hal yang harus diperhatikan dalam konsep technological change dari sudut pandang Islam, yaitu (a) Rasulullah SAW perbah bersabda, "barangsiapa melakukan suatu inovasi sehingga menemukan sesuatu yang baik maka baginya pahala dan orang yang mengambil manfaat darinya"; (b) Islam menyeru untuk melakukan eksplorasi dari apa yang ada di langit dan di bumi untuk kepentingan manusia. Dalam Qur'an terdapat tanda-tanda (S. AlJaatsiyah (25) : 13, "dan dia menundukkan untukmu apa yang ada dilangit dan apa yang ada di bumi semuanya, (sebagai rahmat) dari-Nya. Sesungguhnya pada yang demikian itu benarbenar terdapat tanda-tanda (kekuasaan Allah) bagi kaum yang berpikir"; dan (c) Islam memberikan proteksi dalam setiap inovasi yang diniati untuk kebaikan. Hal ini sesuai dengan semangat hadis: "Barang siapa berijtihat dan benar, maka baginya dua pahala, dan apabila ijtihadnya salah, maka ia mendapat satu pahala." 15

Kedua, pengembangan UKM yang berbasis syariah. Usaha Kecil dan Menengah (UKM) dalam ajaran Islam adalah ajaran yang sangat memperhatikan kepentingan kaum lemah. Dalam QS 59 ayat 7 Allah SWT melarang berputarnya harta (modal) hanya dikalangan orangorang kaya saja. Berdasarkan ayat ini, maka

14 Schumpte, 1972, A. J. The History of Economic Analysis, London: Geoerge Allen And Unwin.

15 Ahmad Izzan,2006, Referensi Ekonom Syariah Ayat-Ayat Al-quran yang berdimensi Ekonomi, Bandung: PT Remaja Rosdakarya 
kita dapat mengambil pelajaran bahwasanya aktivitas perekonomian hendaknya melibatkan partisipasi aktif dari kelompok masyarakat kelas menengah kebawah, yang notabene mereka adalah mayoritas di suatu negara. Tidak hanya didominasi kelompok-kelompok elite saja.

Pengembangan UKM sebagai institusi yang mampu mengaktifkan partisipasi masyarakat harus mendapat perhatian kita semua. Jika kita melihat kenyataan, maka pada umumnya negara-negara muslim di dunia saat ini berada dalam kategori negara berkembang, dimana mereka memiliki surplus jumlah tenaga kerja, kekurangan modal dan alat tukar perdagangan luar negeri, serta minimnya infrastuktur pendidikan dalam pengembangan teknologi. Dengan kondisi tersebut, maka pilihan untuk mengembangkan usaha kecil dan menengah (UKM) merupakan pilihan yang sangat tepat dalam rangka mereduksi pengangguran dan menyerap angkatan kerja yang ada dengan membuka lapangan pekerjaan baru. Bahkan menurut Imam Hasan al-Bana, dalam diskusinya tentang reformasi ekonomi dalam ajaran Islam, usaha kecil dan menengah ini akan mampu membantu menyediakan lapangan kerja produktif bagi keluarga miskin, dan kemudian akan meminimalisir tingkat kemiskinan yang ada.

Muhammad Yunus pun menegaskan bahwa upah pekerjaan bukanlah jalan 'bahagia' dalam mereduksi kemiskinan, tetapi mengembangkan usaha sendiri lebih memiliki potensi untuk mengembangkan basis aset seseorang. Fakta juga membuktikan bahwa strategi industrialisasi dalam skala besar ternyata belum mampu menyelesaikan problematika pengangguran dan kemiskinan secara global. Bahkan dalam sebuah studi yang dilakukan oleh Michigan State University, Amerika Serikat, di sejumlah negara, ternyata ditegaskan bahwa UKM telah memberikan kontribusi nyata yang sangat berharga didalam menciptakan lapangan pekerjaan dan meningkatkan pendapatan.

Di samping itu, UKM ini pun mampu mengembangkan eksport dan mengoptimalkan SDM yang ada, walaupun dengan akses kredit yang sangat minim baik dari pemerintah maupun perbankan. Dalam studi tersebut, juga disimpulkan bahwa UKM ini telah secara konsisten mampu menghasilkan output per unit modal, lebih besar dengan dari apa yang telah dihasilkan oleh industri skala besar. UKM ini telah menjadi alat yang efektif didalam meningkatkan kontribusi sektor privat baik dalam pertumbuhan maupun pemerataan yang obyektif di negara-negara berkembang. Jika kita melihat pengalaman Jepang misalnya, maka salah satu kunci keberhasilan ekspor Jepang yang luar biasa tersebut adalah karena kemampuannya didalam membangun persaingan domestik di antara perusahaan-perusahaan yang memberikan sub kontrak pekerjaan mereka kepada industri UKM. Industri UKM di Jepang telah mampu menghasilkan $50 \%$ dari total keseluruhan output industrinya, dan menyerap $75 \%$ angkatan kerja Jepang. Begitu pula dengan bisnis retailnya, yang 75 persennya dikelola oleh usaha toko keluarga yang dilindungi oleh hukum.

Di Jerman sendiri pun, kesadaran untuk mengembangkan usaha kecil menengah semakin besar, karena ternyata industri rumah tangga mampu memainkan peran signifikan dalam perekonomian Jerman. Tetapi jika kita melihat kondisi Indonesia, maka kita akan sangat miris melihat kenyataan bahwa UKM ini belum mendapatkan perhatian yang memadai dari pemerintah, padahal angka pengangguran kita sangat tinggi, yaitu 40 juta orang atau $18 \%$ dari total keseluruhan jumlah penduduk.

\section{Strategi Pengembangan UKM}

UKM ini di negara-negara muslim termasuk Indonesia perlu didorong perkembangan. Tentunya membutuhkan perubahan yang sangat revolusioner dalam lingkungan sosial ekonomi. Pertama, harus ada perubahan gaya hidup dari ketergantungan terhadap produk impor menjadi kebiasaan mengkonsumsi produk domestik. Ini akan mendorong konsumsi produk dalam negeri yang akan menstimulasi berkembangnya industri dalam negeri.

Kedua, harus ada perubahan sikap dan kebijakan dari pemerintah didalam memandang UKM, bahwa UKM ini harus mendapat dukungan 
penuh. Ketiga, industri UKM ini harus mendapat dukungan dalam mendapatkan input produksi yang lebih baik, teknologi yang tepat guna, teknik pemasaran yang efektif, dan pelayanan lain yang memungkinkan mereka memiliki kemampuan bersaing dengan industri besar, baik persaingan harga maupun kualitas. ${ }^{16}$

Keempat, UKM ini harus mampu meningkatkan skill dan kemampuannya. Tentu saja pemerintah harus menyediakan fasilitas training yang memadai dan institusi pendidikan yang berkualitas. Kelima, industri UKM ini harus diberi akses yang luas terhadap keuangan, dimana hal ini seringkali menjadi sumber masalah yang menghambat perkembangannya.

Keenam, pemerintah harus mampu mengeliminasi berbagai hambatan yang akan merintangi perkembangan dan ekspansi industri UKM. Pencapaian tujuan untuk substitusi impor dan promosi ekspor tidak akan dapat direalisasikan melalui pengembangan UKM jika industri ini tidak dibantu untuk mampu mengembangkan efisiensi teknologi yang memungkinkan mereka untuk bersaing secara efektif. Karena itu adalah langkah yang tepat jika dikembangkannya teknologi tepat guna yang berbasis sumberdaya lokal. Hal ini sangat menguntungkan karena membutuhkan modal yang minimal, cocok diterapkan di negara-negara berkembang yang masih memiliki kelemahan dalam institusi pendidikannya, dan mampu melepaskan diri dari ketergantungan terhadap teknologi impor. Industri UKM ini pun harus didorong untuk dapat berkembang di daerah pedesaan dan kota-kota kecil. Hal ini akan mengurangi perbedaan dan ketimpangan pendapatan secara regional, mereduksi konsentrasi penduduk di daerah kotakota besar semata, meningkatkan pendapatan dan standar hidup, serta akan lebih memeratakan pendapatan dan kesejahteraan.

\section{Menjaga Keunggulan Ekonomi Islam (Islam se- bagai Sistem Memiliki Aturan Sistem yang Berbeda dengan Sistem yang Lain)}

16 Lihat dan bandingkan dengan tulisan Syamsul Rizal, "Pemberdayaan Ekonomi Kerakyatan Menurut Perundang-undangan tentang Usaha Kecil”, Majalah Hukum Vol. 8 No. 2 Agustus 2003 FH USU Medan, hlm. 158-172.
Islam didasarkan pada tiga prinsip pokok yaitu : tauhid, khilafah dan adalah (keadilan), yang jelas pula merupakan sumber utama dari maqasyid dan strategi ekonomi Islam. Batu fondasi percayaan Islam adalah Tauhid. Bahwa alam teralih dirancang dengan sadar dan diciptakan oleh Wujud Tertinggi, Yang Esa dan tidak ada yang menyamai-Nya, bukan terjadi secara kebetulan. Dia terlibat secara aktif dalam hukum-hukum Alam. Segala sesuatu yang diciptakannya mempunyai tujuan. Tujuan inilah yang menjadikan wujudnya Alam ini dimana manusia adalah bagian darinya, berarti penting. Dan manusia adalah khalifah Tuhan di bumi, dan telah diberkahi dengan semua kelengkapannya. Konsep khalifah ini memiliki sejumlah implikasi, atau akibat yang wajar, yatu: persaudaraan universal, sumber-sumber daya adalah amanat, gaya hidup sederhana dan kebebasan manusia.

Islam, dalam hal Ádalah (keadilan) berpandangan bahwa tanpa disertai keadilan sosial ekonomi, persaudaraan ,yang merupakan satu bagian integral dari konsep tauhid dan khilafah, akan tetap menjadi sebuah konsep yang berlubang yang tidak memiliki substansi. Keadilan adalah sebuah ramuan sangat penting dari maqashid, sulit untuk dapat memahami sebuah masyarakat Muslim yang ideal tanpa adanya keadilan di situ. Islam benar-benar tegas dalam tujuannya untuk membasmi semua jejak kezaliman dan masyarakat manusia. Kezaliman adalah sebuah istilah menyeluruh yang mencakup semua bentuk ketidakadilan, eksploitasi, penindasan dan kemungkaran, dimana seseorang mencabut hak-hak orang lain atau tidak memenuhi kewajiban kepada mereka. Penegakan keadilann dan pembasmian semua bentuk ketidakadilan telah ditekankan oleh Al Qurán sebagai misi utama dari semua Nabi yang diutus Tuhan.

Komitmen Islam yang besar pada persaudaraan dan keadilan menuntut agar semua sumber daya yang tersedia bagi ummat manusia, amanat suci dari Tuhan digunakan untuk mewujudkan maqahid asy-Syariah, empat di antaranya cukup penting, yakni: pemenuhan kebutuhan, penghasilan yang diperoleh dari 
sumber yang baik, distribusi pendapatan dan kekayaan yang adil dan pertumbuhan dan stabilitas. Tidak seperti kapitalisme dan sosialisme, tujuan-tujuan islam adalah suatu hasil mutlak dn logis dari filsafat yang mendasarinya. Untuk masyarakat Muslim mewujudkan tujuantujuannya, diperlukan suatu strategi yang juga merupakan hasil logis dari filsafat yang mendasarinya.

Strategi ini meliputi regorganisasi seluruh sistim ekonomi dengan empat unsur penting yang saling mendukung. Pertama, suatu mekanisme filter yang disepakati masyarakat, yaitu moral, dengan mengubah skala preferensi individu sesuai dengan tuntutan khilafah dan adalah; kedua, suatu sistim motivasi yang kuat untuk mendorong individu agar berbuat sebaikbaiknya bagi kepentingannya sendiri dan masyarakat, dengan dasar pertanggung jawaban kepada Tuhan dan Hari Akhir; ketiga, restrukturisasi seluruh ekonomi, dengan tujuan mewujudkan maqashid meskipun sumber-sumber yang ada itu langka, dengan dasar lingkungan sosial yang kondusif untuk menaati aturanaturan pengamatan dengan tidak mengizinkan pemilikan materi dan konsumsi yang mencolok sebagai sumber pretise; dan keempat, suatu peran pemerintah yang berorientasi tujuan yang positif dan kuat.

Pihak nasabah dalam dunia perbankan merupakan unsur yang sangat berperan sekali, mati hidupnya dunia perbankan berstandar kepada kepercayaan dari pihak masyarakat atau nasabah. ${ }^{17}$ Dari segi internal perbankan syariah dengan sedikit mengutip dari hasil Islamic Financial Institutions Forum di Bahrain tahun 1998, beberapa faktor kunci sebagai persiapan perbankan syariah menuju abad mendatang agar dapat hadir pada perbankan modern dan memiliki daya saing yang handal. Sumber daya manusia (SDM) merupakan faktor penentu dalam membangun bank syariah yang solid dan profesional. Bank syariah memerlukan

17 Syamsul Hoiri, "Lembaga Medisasi Perbankan: Sejauh Mana Efektivitasnya?," Jurnal hukum Bisnis Volume 28No.2-Tahun 2009, hlm. 47.
SDM yang memiliki dua sisi kemampuan yaitu ketrampilan pengelolaan operasional (profesionalism) dan pengetahuan syariah yang dilengkapi dengan akhlak dan integritas yang tinggi. Faktor kedua adalah kemampuan bank dalam menyediakan produk dan jasa bank yang dapat memenuhi kebutuhan masyarakat. Dengan demikian akan berkaitan erat dengan kemampuan dalam pengembangan produk yang kompetitif dan melayani segmen nasabah potensial. Pengembangan produk bank akan berperan kuat SDM bank, institusi pengawas produk dan jasa bank yaitu dewan pengawas syariah dan dewan syariah nasional.

Namun demikian keahlian dan pengetahuan SDM bank akan menjadi pemain utama yang menentukan. Faktor ketiga adalah pengembangan teknologi bank termasuk teknologi sistem informasi. Teknologi sistem informasi yang tepat guna akan menjadikan bank beroperasi lebih efisien. Di beberapa negara kaya minyak di timur tengah (Bahrain, Arab Saudi, Kuwait, Qatar, UAE) kecanggihan teknologi informasi bank syariah sangat menonjol, sehingga mampu menyediakan data dan pelayanan jasa kepada masyarakat melalui produk-produk bank yang modern seperti phone banking, smart card, financing/investment products, dan lain-lain. Faktor-faktor tersebut merupakan penentu keberhasilan yang bersifat mendasar, tentunya masih banyak faktor lain yang juga turut menentukan keberhasilan bank syariah dengan memperhatikan kondisi lingkungan bisnis, geografis, sektor industri yang potensil, serta heterogenitas budaya masyarakat di suatu daerah atau negara yang tentunya berbeda. Namun demikian kita semua patut bersyukur dengan perkembangan perbankan syariah yang mulai menunjukkan eksistensinya sebagai suatu sistem perbankan yang memiliki manfaat dalam perekonomian umat muslim khususnya serta bagi anggota masyarakat non-muslim lainnya sebagai rahmat bagi seluruh umat manusia menjelang millenium baru, suatu tantangan pengembangan dan juga suatu harapan bagi kemajuan perekonomian.

Ada 5 (lima) keunggulan Bank Syariah yang belum diketahui oleh banyak orang. 
Pertama, fasilitas selengkap bank konvensional. Banyak orang yang berpikiran bahwa karena perbankan syariah masih baru, jenis transaksi yang dapat dilakukan hanya sedikit. Anggapan tersebut dulu mungkin bisa dimengerti, tapi sekarang sama sekali tidak benar. Bank Syariah saat ini sangat modern. Semua jenis transaksi mulai dari tabungan, deposito, kredit usaha, kredit rumah, kliring, dan sebagainya dapat dilakukan dengan nyaman.

Mayoritas Bank Syariah terhubung dengan jaringan online ATM Bersama sehingga Anda dapat tarik tunai dan transfer realtime dari/ke bank lain dengan mudah. Beberapa Bank ada yang menggratiskan biaya untuk ini. Beberapa Bank Syariah yang memberikan layanan Internet Banking, SMS Banking, bahkan kartu kredit syariah sehingga lebih praktis.

Kedua, manajemen finansial yang lebih aman. Tragedi finansial kredit subprime tahun 2007 nyaris tidak menggoyahkan investasi yang berbasis syariah. Di saat banyak bank investasi dan bank-bank besar bangkrut maupun membutuhkan kucuran dana, banyak Bank Syariah baru yang justru bermunculan atau buka cabang. Krisis ekonomi justru telah memuktikan bahwa manajemen finansial berbasis syariah jauh lebih aman dibandingkan ekonomi liberal yang dianut bank konvensional.

Ketiga, anda berkontribusi langsung memperkuat bank syariah anda. Bank konvensional menentukan sendiri suku bunga pinjaman maupun simpanan berdasarkan ketetapan Bank Indonesia. Ada kemungkinan meski kondisi bank kurang baik, tetap dapat "memberikan" bunga simpanan tinggi dan bunga kredit rendah. Hal ini dapat membahayakan bank tersebut. Bank Syariah memberikan nisbah ("bunga" simpanan) berdasarkan perkembangan finansial perusahaan. Secara tidak langsung Anda menjadi "pemegang saham" di Bank Syariah Anda. Setiap simpanan Anda akan memperkuat investasi bank. Setiap pinjaman Anda akan memperkuat keuntungan bank. Semakin usaha Anda berkembang, bank juga semakin berkembang karena kredit yang diberikan menggunakan skema bagi-hasil. Semakin maju bank, semakin banyak pula keuntungan bank yang dapat dibagikan sebagai nisbah kepada para nasabah.
Keempat, membantu orang yang butuh dizakati. Bank Syariah mengeluarkan 2,5\% dari keuntungan tahunannya untuk dizakatkan. (Anda sendiri tentunya masih harus berzakat bila Anda muslim.) Namun bank konvensional tidak mempunyai kewajiban berzakat. Dengan menggunakan layanan Bank Syariah, secara tidak langsung Anda turut berzakat dan membantu mereka yang membutuhkan.

Kelima, satu langkah awal menuju halal. Transparansi informasi mengenai produk bank sangat diperlukan untuk memberikan kejelasan kepada nasabah mengenai manfaat dan risiko yang melekat pada produk tersebut. Selama ini nasabah bank khususnya nasabah kecil selalu saja berada di pihak yang dirugikan bila berhadapan dengan bank. ${ }^{18}$ Kredit yang diberikan oleh bank syariah mempunyai persyaratan yang bertujuan agar aktivitas yang berhubungan dengan bank syariah bersifat halal. Bisnis yang dibiayai bank syariah, sesuai ketentuan yang berlaku, juga membatasi kemungkinan terlibatnya kegiatan yang diharamkan oleh syariat Islam. Hal ini sama sekali tidak membatasi nasabah bank syariah harus muslim, justru agama apa pun boleh, asal halal pemakaiannya. Meskipun nasabah tersebut muslim, tapi jika pemakaian dana atau usaha yang dijalankannya tidak halal, maka dia tidak diperkenankan untuk mengambil kredit di Bank Syariah.

\section{Larangan Islam terhadap Mekanisme Ekonomi Berbasis Bunga}

Ada perbedaan pendapat dalam Islam bahwa setiap laba yang berlebih-lebihan dalam pertukaran barang atau uang ataupun penumpukan barang tanpa memperdulikan perbedaan baik dan buruknya adalah sama dengan riba, termasuk laba lebih yang didapat dari pertukaran emas dan perak sedang logam tersebut tetap serupa seperti semula juga merupakan riba. Dalam Islam, meskipun diakui adanya hak atas benda, tetapi di dalamnya terdapat hak-

18 Zulkarnain Sitompul, "Antisipasi Krisis Perbankan Jilid Dua: Sudah Siapkah Pranata Hukum Melindungi Nasabah dan Memperkuat Industri Perbankan?," Jurnal Hukum Bisnis, Volume 28-No.1-Tahun 2009, hlm. 48. 
hak pihak lain seperti, kepentingan umum, orang miskin, yang pendistribusiannya melaui zakat infaq, dan sedekah. Penimbunan harta dengan mengabaikan orang miskin dan anak yatim tidak dapat diterima oleh Al-Qur'an. Pelarangan riba di dalam Al-Qura'an tidak terlepas dari prinsip-prinsip ini. Apabila diperhatikan lebih lanjut, maka penimbunan (penyimpanan) harta dalam bentuk emas dan perak tanpa tujuan tertentu merupakan kejahatan besar; "Kecelakaanlah bagi setiap pengumpat lagi pencela, yang mengumpulkan harta dan menghitung-hitungnya, dan mengira bahwa hartanya itu dapat mengekalkannya".

Adapun dampak yang disebabkan dari praktek riba dalam masyarakat adalah sebagai berikut. Pertama, dampak riba dari segi kognisi. Kelebihan manusia dengan makhluk lainnya di antaranya adalah "Manusia memiliki kemampuan untuk mengembangkan ilmu pengetahuan yang berpangkal dari kecerdasan otak atau intelektualitas yang disebut dengan kemampuan kognitif." 19 Dengan kemampuan kognitif ini, manusia dapat mengalami perubahan tingkah laku secara sadar dan cepat. Termasuk kemampuan mengadakan reaksi terhadap rangsangan dari luar. Oleh karena itu Islam menganjurkan agar kemampuan berfikir ini dibangun pada seseorang sesuai dengan fitrah manusia yang cenderung untuk menerima kebenaran AlQur'an dan aturan-aturan yang ada di dalam Islam. Bila kita lihat ayat-ayat Al-Qur'ân bahwa Allah telah meletakkan kaedah-kaedah dasar untuk berfikir ilmiyah, yaitu: "Sebuah proses berfikir yang diawali dengan pengamatan, menghimpun data, menarik kesimpulan, dan terakhir memverivikasi (pemeriksaan tentang kebenaran laporan, pernyataan) kembali kebenaran kesimpulan yang telah diambil."20

Ada beberapa kesalahan di dalam berfikir bagi orang-orang yang cenderung untuk menghalalkan riba dan berhubungan dengan sistem ribawi. Kesalahan itu adalah sebagai berikut: berfikir yang menyimpang dari fitrah manusia-

19 M. Arifin dan Aminuddin Rasyad, 1997, Materi Pokok Dasar-dasar Pendidikan, Cet. VI, Jakarta: Ditjen Binbaga Islam, hlm. 117.

20 M. Usman Najati, 2003, Psikologi dalam Tinjauan Hadith Nabi, terj. Wawan Djunaedi Soffandi, Cet. I, Jakarta: Mustaqim, hlm. 184. wi, dan berfikir egoisme dan untuk keuntungan pribadi serta tidak mempedulikan kemeslahatan orang banyak.

Abdul Mujib (dengan mengutip pendapat Ibnu Mansur dan Al-jurjany) dalam hal berfikir menyimpang dari fitrah manusia, menjelaskan bahwa "Fitrah adalah kondisi konstitusi dan karakter yang dipersiapkan untuk menerima agama." 21 Dengan demikian orang yang tidak mengindahkan perintah agama berarti telah menyimpang dari fitrah manusiawi yang benar.

Berfikir egoisme dan untuk keuntungan pribadi serta tidak mempedulikan kemeslahatan orang banyak. Berfikir taqlid dan mengekor pada sistem riba dari orang kafir dengan tidak melakukan verivikasi terlebih dahulu tentang kebenaran pendapat tersebut. Padahal Rasulullah mengingatkan umat manusia agar tidak mengikuti dan bertaqlid kepada pendapat orang lain dalam melakukan aktivitasnya sebagaimana taqlid orang buta yang tidak lagi bisa melihat dengan jelas.

Kedua, dampak riba dari segi afeksi. Afeksi merupakan "Hal-hal yang menyangkut dengan sesuatu yang berhubungan dengan sikap, perasaan, tata nilai, minat dan apresiasi". ${ }^{22}$ Nilai-nilai afektif ini yang berpengaruh bagi seorang muslim dalam menata kehidupannya di dunia dan dalam berhubungan dengan masyarakat. Orang yang memiliki sikap (akhlak) yang baik di dalam masyarakat akan disegani dan dihormati.

Orang yang telah terpengaruh dengan riba akan mengalami sikap dan emosional yang tidak stabil dalam hidupnya. Dari ketidakstabilan dalam hidup akan melahirkan sifat-sifat dan sikap-sikap yang tercela yang sangat dibenci dalam ajaran Islam. Sifat atau sikap tercela yang dapat merusak pribadi dan masyarakat akibat dari praktek riba adalah sombong; kikir; timbulnya sifat tamak; dan hilangnya rasa kasih sayang. Dalam hal ini A.M. Saefuddin mengutip pandangan Sayid Qutb menjelaskan: "Perbuatan riba hanya akan merusak nurani akhlak dan perasaan tiap individu terhadap saudaranya

\footnotetext{
21 Abdul Mujib, 2000, Fitrah dan Kepribadian Islam Sebuah Pendekatan Psikologis, Cet. I, Jakarta: Darul Falah, April, hlm. 34.

22 M. Arifin dan Aminuddin Rasyad, op.cit, hlm. 118
} 
sejama'ah, dan merusak kehidupan sosial yang ditimbulkan oleh sifat loba, tamak, egois, curang dan spekulatif". ${ }^{23}$

Rasa kasih sayang merupakan ciri khas Rasulullah, para sahabat dan umat Islam secara keseluruhan. Terutama sekali kasih sayang sesama muslim itu sendiri. Rasa kasih sayang adalah "Perasaan halus dan belas kasihan di dalam hati yang membawa kepada berbuat amal yang utama, memberi maaf dan berlaku ihsan". ${ }^{24}$

Ketiga, dampak riba dari segi perilaku. Dari sisi lain, pengaruh dari praktek riba akan melahirkan perilaku yang menyimpang dari aturan agama dan menyebabkan kerusakan individu dan sosial. Di antara perilaku yang menyimpang yang lahir dari praktek riba adalah berperilaku boros; terjadinya pemerasan orang kaya terhadap orang miskin; dan dampak riba dari segi persepsi.

Akibat dari persesi yang seperti ini akan dapat merusak hubungan sesama manusia. A.M. Saifuddin dalam hal ini menegaskan bahwa sistem riba akan memperlebar jurang pemisah antara sesama manusia, dan mempercepat proses pemelaratan dan kesengsaraan hidup, baik secara individu, jama'ah, negara maupun bangsa, akan sistem yang berlaku bagi kemeslahatan segelintir manusia pelaku riba, dan berakibat negatif bagi orang banyak karena merusak moral, turunnya wibawa dan harga diri. Peredaran harta menjadi tidak merata, sementara pertumbuhan ekonomi terus berjalan menuju tujuan akhir, sebagaimana kita saksikan sekarang ini yaitu sentralisasi yang sangat dominan di bawah tangan segelintir manusia yang paling jahat dan paling tidak memeliki tanggung jawab moral dan tidak kenal haram dan halal. ${ }^{25}$

Keempat, dampak riba dari segi rohani. Rasulullah mengajak para sahabatnya untuk senantiasa beriman kepada Allah, mendekatkan diri kepadanya, melakukan segala sesuatu yang diridhai Allah, meyakini keesaan Allah dan me-

23 A.M. Saefuddin, 1987, Ekonomi dan Masyarakat Dalam Perspektif Islam, Cet. I, Jakarta: Rajawali, hlm. 240.

24 M. Hasbi As-Siddiqiey, 1977, Al-Islam, jilid I, Cet. V, Jakarta: Bulan Bintang, hlm. 479.

25 A.M. Saifuddin, op.cit, hlm. 233-234. minta pertolongan kepada Allah Akan tetapi sebaliknya bagi orang yang berdosa dan para pemakan riba akan sangat merugikan mereka sendiri dan mendapat siksa dari Allah baik di dunia maupun di akhirat. Adapun dampak riba bagi para pemakan riba dalam agama dan dari segi rohani adalah sebagai berikut: para pemakan riba tidak cenderung untuk membantu fakir miskin; dan riba merupakan perbuatan yang bathil dan mendapat siksa dari Allah.

\section{Penutup \\ Simpulan}

Ada beberapa tantangan ekonomi syariah yang harus di hadapi oleh bangsa Indonesia untuk menuju kemajuan ekonomi syariah. Pertama, sistem kapitalis terlanjur mendominasi sistem perekonomian di dunia bahkan banyak Negara yang notabene berpenduduk Islam cenderung menggunakan sistem kapitalis walaupun dalam penerapannya terdapat modifikasi; kedua, sulitnya untuk membuktikan bahwa Sistem Perekonomian Islam lebih unggul daripada kapitalis dan sosialis, karena Negara Islam di pandang tidak kuat secara ekonomi dan politik; dan ketiga, pengertian Sistem Perekonomian Islam diantara para ahli sendiri masih silang pendapat;

Ekonomi syariah dalam menghadapi masa depan indonesia di era globalisasi kiranya perlu menyiapkan diri dengan memperhatikan beberapa faktor, diantaranya adalah penguasaan teknologi; pengembangan ukm berbasis syariah; dan menjaga keunggulan ekonomi syariah, yaitu sistem ekonomi syariah, dan juga pelarangan riba.

\section{Daftar Pustaka}

As-Siddiqiey, M Hasbi. 1977. Al-Islam, jilid I. Cetakan. V. Jakarta: Bulan Bintang;

Breeden, Richard C. "The globalization of Law and Business in the 1990". Wake Forest Law Review. vol. 28 No.3. 1993;

Cavusgil, S Tamer. "Globalization of Markets and Its Impact on Domestic Institutions". Global Legal Studies Journal. Vol 1. 1993; 
Chirot, Daniel. 1986. Social Change in The Modern Era. San Diego. New York: Harcourt Brace Jovanovich. Inc;

Delors, Jaqnes. "The Future of Free Trade in Europe and the World". Fordham International Law Journal. Vol. 18 1995.;

Dimyati, Khudzaifah \& Kelik Wardiono (ed). 2004. Problema Globalisasi Perspektif Sosiologi Hukum, Ekonomi dan Agama. Surakarta: Muhammadiyah University Pers;

Edward, Kwakwa. 2000. "Regulating The International Economy, What Role For The State" dalam Michael Byers;

Fasseur, C. 1986. "The Cultivation Sistem and Its Impact on the Dutch Colonial Economy and the Indigenous Society in Nineteenth Century Java". dalam Two Colonial Empires, ed, C.A, Bayly and DH.A.Kolf. Dordrecht: Martinus Nijhoff Publishers;

Frank, Thomas N. “The New Development, Can American Law and Legal Institution Help Developing Countries?". Wisconsin Law Review. 1989;

Fukuyama, Francis. 2001. Kemenangan Kapitalisme dan Demokrasi Liberal (Diterjemahkan dari judul asli The End of History and The Last Man) Yogyakarta: Qalam;

Giddens, Anthony. 1986. Kapitalisme dan Teori Sosial Modern (Suatu analisis karya-karya Marx, Durkheim dan Max Weber). Jakara: UI Press;

Hali, Damianus J. "Humanisme dan Peradaban Global”. Jurnal Hukum Pro Justitia Vol. 26 No. 2. April 2008. Bandung: FH Unpar;

Hendrarto, Conrad. 2008. "Ambruknya Kapitalis dan Saat Bangkitnya Ekonomi Syariah;

Hoiri, Syamsul. "Lembaga Medisasi Perbankan: Sejauh Mana Efektivitasnya?". Jurnal Hukum Bisnis. Vol. 28 No.2. Tahun 2009;

Izzan, Ahmad. 2006. Referensi Ekonom Syariah Ayat-Ayat Al-quran yang berdimensi Ekonomi. Bandung: PT Remaja Rosdakarya;

Muhammad. 2004. Ekonomi Mikro dalam Perspektif Islam. Yogyakarta: BPFE;

Mujib, Abdul. 2000. Fitrah dan Kepribadian Islam Sebuah Pendekatan Psikologis. Cetakan I. Jakarta: Darul Falah. April;

Najati, M Usman. 2003. Psikologi dalam Tinjauan Hadith Nabi. terj. Wawan Djunaedi Soffandi. Cetakan I. Jakarta: Mustaqim;

Neil, Robert Van. 1964. "The Function of Land Rent Under the Cultivation Sistem in Ja- va”. Journal of Asian Studies 23. London: Oxford University Press;

Purba, Victor. "Peranan Hukum dalam Global Kompetisi pada Era Globalisasi”. Majalah Hukum Pro Justitia. Tahun 12 No. 2 April. 1994. Bandung: FH Unpar;

R E Elson, 1984, Javanese Peasants and the Colonial Sugar Industri. London: Oxford University Press;

Rahardjo, Satjipto. Pembangunan Hukum di Indonesia Dalam Konteks Situasi Global, dalam Khudzaifah Dimyati \& Kelik Wardiono (ed.), 2004, Problema Globalisasi Perspektif Sosiologi Hukum, Ekonomi dan Agama. Surakarta: Muhammadiyah University Pers, hlm. 12;

Rasyad, Aminuddin dan M. Arifin. 1997. Materi Pokok Dasar-dasar Pendidikan. Cet. VI. Jakarta: Ditjen Binbaga Islam;

Rizal, Syamsul. "Pemberdayaan Ekonomi Kerakyatan Menurut Perundang-undangan tentang Usaha Kecil". Majalah Hukum. Vol. 8 No. 2. Agustus 2003. Medan: FH USU;

Rosita, Dian. 2010. "Kedaulatan Negara dalam Pembentukan Hukum di Era Globalisasi". Jakarta; I http:// www.leip.or.id/;

Saefuddin, A M. 1987. Ekonomi dan Masyarakat Dalam Perspektif Islam. Cetakan I. Jakarta: Rajawali;

Schumpte. 1972. A. J. The History of Economic Analysis. London: Geoerge Allen And Unwin;

Sitompul, Zulkarnain. "Analisis Hukum Kewenangan Lembaga Penjamin Simpanan Dalam Pembubaran Dan Likuidasi Perseroan Terbatas". Jurnal Hukum Bisnis. Vol. 28 No. 3. Tahun 2009;

Sitompul, Zulkarnain. "Antisipasi Krisis Perbankan Jilid Dua: Sudah Siapkah Pranata Hukum Melindungi Nasabah dan Memperkuat Industri Perbankan?". Jurnal Hukum Bisnis. Vol 28 No.1. Tahun 2009;

Soenandar, Taryana. "Perdagangan Bebas dan Harmoni-sasi Hukum: Kajian atas Doktron "Lex Mercatoria”. Jurnal Keadilan Vol. 1 No. 5 November-Desember 2001;

Trubek, David M. "Max Weber on Law and The Rise of Capi-talisme". Winconsin Law Review. Vol 3. 1992;

Wright, HRC. 1961. East-Indian Economic Problem of the Age of Cornwallis \& Raffles. London: Inzac and Company. Ltd. 